\section{Policy transfer from advanced to less-advanced institutional
environments: Labour market
orientations of US MNEs in Turkey to less-advanced institutional
environments: Labour market
orientations of US MNEs in Turkey to less-advanced institutional
environments: Labour market
orientations of US MNEs in Turkey}

@SAGE

\author{
Kadire Zeynep Sayım \\ Bilkent University, Turkey
}

\begin{abstract}
The extant research on policy transfer insufficiently addresses two issues. First, transfer to less-advanced countries. Second, micro-institutional pressures on subsidiaries, particularly the role of local partners in joint ventures (JVs). This study investigates the transfer of labour market orientations by American multinational enterprises to their Turkish subsidiaries by focusing on the influences of macro- and micro-institutional factors when the 'transferor' is an advanced and 'transferee' is a less-advanced economy, 'dominance effects', and the role of local JV partners. Case study findings provide evidence for 'smooth' transfer of the policy. This uncommon finding is discussed as a result of 'ideal combination' of 'encouraging pressures' at the macro- and micro-institutional levels, including role of local JV partners and the nature of the policy transferred.
\end{abstract}

\title{
Keywords
}

international human resource management, joint ventures, labour market orientations, less-advanced countries, policy transfer

\section{Introduction}

A key theme in the international human resource management (IHRM) concerns the 'global - local question' (Edwards and Kuruvilla, 2005): how do multinational enterprises (MNEs) control international operations through globally-integrated and standardized human resource (HR) policies, while also responding to the 'local isomorphic' pressures to become similar to the firms in the host-country (Ferner and Quintanilla, 
1998)? This line of research has recently seen a considerable growth, considering the macro-institutional influences with a comparative institutionalist (e.g. Edwards and Ferner, 2002), micro-institutional influences with new institutionalist (e.g. Kostova and Roth, 2002), or more rarely, both sets of influences with a combined institutionalist perspective (e.g. Ferner et al., 2005a; Tempel et al., 2006).

This article focuses on three issues inadequately addressed in the extant literature: first, despite repeated calls for an extension of the range of countries and business systems studied, research still focuses mainly on the operations of MNEs from and in advanced economies. Might there be any theoretically important issues not articulated in the literature when the transfer is intended from an advanced economy to a less-advanced (e.g. emerging) one, especially considering potential 'dominance effects' (Smith and Meiksins, 1995)? A second important point is about 'institutional duality', defined as pressures on the subsidiaries for internal and external legitimacy emanating from their MNE parent and host-country institutional environments, respectively (Kostova, 1999; Kostova and Roth, 2002; Kostova and Zaheer, 1999). While institutional duality is considered as an important influence on the policy transfer, only the 'foreign' MNEs' potential pressure is formulated as an organizational-level influence, neglecting that of 'local' (host-country) parent(s) in the case of joint ventures (JVs). In fact, JVs present an extensive entry mode particularly to less-advanced economies (e.g. China). Local JV partners potentially have a significant governance role in the subsidiaries while the latter depend on them for obtaining a range of resources (e.g. expertise, managerial, and administrative skills). A second question is therefore about the likely dual pressure subsidiaries face at the organizational level originating from both their parents, i.e. 'foreign' and 'local', when the governance structure is a JV. Moreover, while the pressures from the local JV partner are internal to the firm and micro-level, their relationship to broader host pressures for isomorphism is not all that clear. Are JV partners merely additional 'transmission belts' for host pressures, or do they add a separate, distinctive dimension to local isomorphic pressures? Lastly, more emphasis is needed on the nature of the specific policy considered for transfer. Some policies can be more prone to resistance from subsidiaries, resulting in avoidance of, and non-compliance with, corporate pressures for the transfer (see Tempel et al. [2006] on collective representation and Ferner et al. [2005a] on diversity policies). Consequently, might others be more 'suitable' for transfer, despite significant differences between host- and home-country institutional environments?

This article addresses these issues by using case study evidence of labour market orientations (LMO) in American MNEs in Turkey. For the purposes of this study, LMO are defined as the preferred recourse by the organization to internal or external labour markets when recruiting for open positions. LMO constitute a significant aspect of corporate policy as they have the capacity to shape related HR policies, i.e. selection, training and development, and compensation. More specifically, the research questions are: how do the micro- and macro-institutional pressures for isomorphism influence policy transfer by US MNEs from an advanced, dominant economy to a less-advanced hostcountry, i.e. Turkey? Within this context, do host JV parents, as governance actors, exert any notable influences? Does the specific policy investigated, i.e. LMO, make any difference on the acceptance/refusal of the transfer?

The article is organized as follows: the next section develops a framework for exploring the influences of home- and host-country institutional systems on MNEs' LMO, 
paying particular attention to the issues of 'dominance' and 'institutional duality'. In the following section the most relevant features of the Turkish business system (TBS) are delineated comparatively with those of the USA, and the institutional distance in terms of the LMO between the two systems is discussed. The method section is followed by the presentation of case study evidence on LMO. The discussion draws out the implications of the findings, in particular for an understanding of policy transfer from advanced economies to less-advanced ones, role of JV partners, and the nature of the policy transferred.

\section{Macro- and micro-level influences on policy transfer}

Studies using the comparative institutionalism focus on the influences of home- and host-country national business systems (NBS) on the transfer and adaptation of HRM policies and practices (e.g. Almond et al., 2006; Edwards et al., 2007; Ferner et al., 2001, 2004). They contend that MNEs are "embedded" in their own NBS that comprise interlocking structures and institutions that fundamentally shape the nature of markets, competition, and business activity in general' (Ferner and Tempel, 2006: 12). This framework argues that MNEs develop their HRM policies in response to key home-country national institutions. It stresses the significance of two major factors that shape firm behaviour. First, the 'interaction effects', i.e. the dominant and mutually supportive national institutions developed as a result of historical paths that favour certain kinds of market arrangements. Second, 'institutional complementarities', which emphasize the connection between market organization and market-hierarchy relations (Deeg and Jackson, 2007).

New institutionalism is concerned with how institutional effects are diffused within 'organizational fields', i.e. 'the set of organizations that in the aggregate, constitute a recognized area of institutional life' (DiMaggio and Powell, 1983: 143). It argues that organizations tend to adopt similar practices and perspectives to be 'isomorphic' with others in the same field. The driving force behind conformity to institutional pressures is efforts to gain legitimacy, defined by Suchman (1995: 574) as:

... a generalized perception or assumption that the actions of an entity are desirable, proper, or appropriate within some socially constructed system of norms, values, beliefs, and definitions.

New institutionalist studies mostly deal with the transfer of practice from the parent company to subsidiaries at the organizational level, where subsidiaries face 'institutional duality' (Kostova, 1999; Kostova and Roth, 2002; Kostova and Zaheer, 1999). To gain legitimacy, subsidiaries must successfully deal with two sets of isomorphic pressures: first, from the host country's distinct institutional environment with its own institutional and relational contexts; and second, from the parent company that mandates the subsidiary to adopt the former's corporate practices (Kostova and Roth, 2002). Kostova and Roth (2002: 217) propose that the first set of isomorphic pressures, i.e. the effects of the host institutional context, can be systematically examined by using an 'institutional profile', defined as 'the issue-specific set of regulatory, cognitive, and normative institutions in a given country'. Institutional distance, i.e. the difference or similarity between the institutional profiles of the home and host countries, is argued to mediate the challenges imposed by institutional duality (Kostova, 1999; Kostova and Roth, 2002). Kostova 
(1999) argues that when the institutional distance is greater there will be a higher need to adopt organizational practices to achieve external legitimacy, while it will also be more difficult to understand the host environment and its legitimacy requirements. By the same token, 'favourable' institutional environments, where the institutional profile influences the adoption positively, will encourage the adoption (Kostova and Roth, 2002).

A second set of isomorphic pressures exists at the organizational level coming from the parent company, which is defined by dependence, trust, and identity relations between the parent and subsidiary (Kostova and Roth, 2002). If the subsidiary needs to rely on the parent company for major resources such as technology, capital, and expertise, this dependence will positively influence implementation of an organizational practice dictated.

While earlier studies claim that subsidiaries are submissive actors in responding to parent company pressure to adopt home-country practices (e.g. Rosenzweig and Singh, 1991), more recently different forms of subsidiary responses are identified. Using Oliver's (1991) framework, they vary from minimal to active adoption (Kostova and Roth, 2002), from resistance to accommodation (Ferner et al., 2005a), and include the range of proactive responses, from compromising with to strategically complying with (Tempel et al., 2006: 1564). Tempel et al. (2006) conclude that while institutional distance can give a broad idea about the (dis)similarities between home- and host-country institutions, it is not possible to understand subsidiary practices without considering the dependencies that host-country institutions can create, or subsidiary managers can use, against the parent company.

Although the contributions of these studies to understanding the various aspects of policy transfer in MNEs are highly acknowledged, this article focuses on three aspects that the extant research has largely neglected. First, the literature almost entirely focuses on the transfer of policies in the 'Triad', i.e. the EU, the USA, and Japan, which exemplify the advanced economies. There is a definite need to understand how macro- and micro-institutional influences work when the transfer is intended from an advanced economy to a less-advanced one, particularly where power relations between countries are important (Elger and Smith, 2006; Kostova, 1999; Smith and Meiksins, 1995). Smith and Meiksins (1995) argue that 'dominance effects', i.e. the transfer of 'best practices' by the 'dominant' economies/societies, should be amalgamated with the interaction of society (institutional and cultural) and systems effects. The extent and direction of transfer depend on a number of conditions, including the relative positions of the 'transferor' and 'transferee' in the global economic system, and the nature of the solution the transferred practice provides for problems at the receiving end (Smith and Meiksins, 1995: 261263). The relational ties between the sender and receiver countries are among the key factors that define the process and outcome of the transfer (Üsdiken, 2004). The relative dependence of one country on another economically and/or politically might be instrumental in facilitating the transfer (e.g. Arias and Guillén, 1998). Moreover, the historical economic and developmental backwardness of the receiver country can create a traditional openness to transfer and emulation of knowledge and practices (cf. Üsdiken, 2004), resulting in a national enthusiasm for importing from abroad, i.e. 'active importing' (Bjarnar and Kipping, 1998). The smooth transfer from a 'dominant' advanced economy to an 'active importer', less-advanced one can therefore result in an adopted policy, 
rather than adaption or translation (Kipping et al., 2008). While the power and dominance issues are conceptualized theoretically, they have not been investigated for the transfer of HR policies by MNEs from advanced economies to subsidiaries in lessadvanced ones.

Secondly, influences of different constituents and the organization's dependence on them are important as an organization's response to institutional pressures is shaped by the multiplicity of demands (Oliver, 1991). A significant constituent insufficiently researched is local JV partners that can have a direct effect on subsidiary policies through the joint governance structures. Isomorphism pressures at the organizational level are assumed to be related to the parent-company, i.e. the MNE (Kostova, 1999; Kostova and Roth, 2002; Taylor et al., 1996). In fact, such pressures may emanate from several organizational actors in the local environment, including most directly from local JV partners, as there are usually governance as well as dependence, identity, and trust issues. JVs constitute a significant governance structure in foreign direct investment (FDI) although a limited number of studies have so far investigated the implications of shared ownership on the transfer of home-country policies and host-country applications adopted (e.g. Guest and Hoque, 1996; Lu and Bjorkman, 1997; Martinez and Ricks, 1989; Shenkar and Zeira, 1987; see also Hartmann et al., 2010 for a recent but rare example). Martinez and Ricks (1989) find that the parent on whom the subsidiary is more resource-dependent is more influential on the HR decisions of US companies in Mexico. While the ability of the local partner to use its expertise and knowledge to access raw materials and local markets is a source of influence, control of product and process technologies are found to be the main source of power in decision-making (Shenkar and Zeira, 1987).

Moreover, the nature of pressures from the local JV partners can be specified in relation to those from the host NBS. While the former are more clearly micro-level and internal to the firm, their relationship to broader host-country pressures for isomorphism are not easily apparent. Local JV partners are 'embedded' in the host-country NBS and their policies are developed in response to the same business environment as where the subsidiary operates. Whether they are only additional 'transmission belts' for host pressures or add a distinctive dimension to local isomorphic pressures is a theoretically significant issue.

Lastly, the role of the specific policy/practice intended for transfer needs to be more clearly identified. Extant literature generally focuses on problems in the transfer of HRM policies, e.g. resistance by local subsidiary, resulting in hybridization or various avoidance strategies (e.g. Almond and Ferner, 2006; Gooderham et al., 1998; Schmitt and Sadowski, 2003; Tempel et al., 2006). While pay and performance (e.g. Almond et al., 2006; Björkman and Furu, 2000; Bloom et al., 2003) and collective representation (e.g. Beaumont and Townley, 1985; Ferner et al., 2005b; Tempel et al., 2006) are among the most covered, employment systems (e.g. Colling and Clark, 2002) or diversity management (Ferner et al., 2005a), as well as the role of the nature of these policies/practices on the transfer, are acknowledged less.

The framework used to investigate the above-mentioned issues therefore incorporates the governance structure and role of local JV partners to the macro-influences of NBS and micro-influences of MNEs. To understand how transfer occurs between advanced 


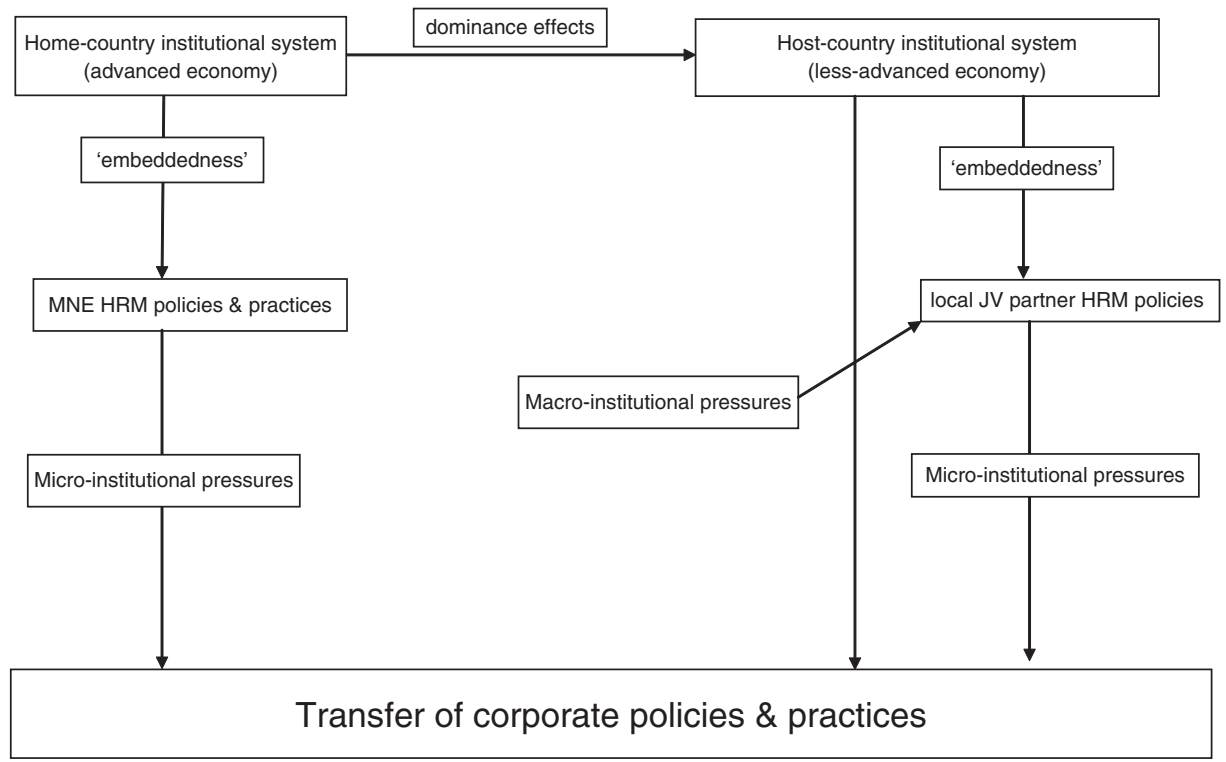

Figure I Research framework

and less-advanced economies within this framework, host- and home-countries are selected accordingly. The article focuses specifically on LMO to explore the role of the policy transferred.

\section{National business systems and institutional distance}

\section{Institutional systems:Turkey and the US}

Berkman and Özen (2007) suggest that the TBS has evolved from a state-dependent to a state-coordinated system. Among its two major characteristics are: first, the strong state that still actively coordinates and controls economic activities; and second, the big business groups, i.e. 'holdings', created by the former (Gökşen and Üsdiken, 2001). The Turkish private sector started to gain a larger share in the economy only in the $1950 \mathrm{~s}$ (Buğra, 1994) and continued to grow into the 1970s within the protected environment of the state-planned, inward-looking, 'import-substitution' economy (Kepenek and Yentürk, 2000). Incentives and other measures in the import-substitution strategy, tax, and financial advantages helped establish family-controlled big 'holdings' in the 1960s, which exemplify the nature of the corporation in Turkey (Çolpan, 2010). The Turkish holding structure, with its diversified nature, and role of the state in its establishment and development, is comparable to similar structures in lately industrialized countries, for example, the Korean chaebol (Buğra and Üsdiken, 1995). Turkish holdings have a significant role in the Turkish economy, owning the majority of the largest industrial companies 
(Berkman and Özen, 2007) and they also make it in international rankings (e.g. World's Largest 500 Companies by Forbes in 2006). Çolpan (2010) claims that the 'holding' strictly controls its affiliate firms in three main areas: investment decisions, financial coordination, and HRM policies - especially LMO and reward management.

The USA became Turkey's key economic, political, and military ally during the 1950 s, around the same period when the USA started to penetrate foreign markets. Turkey was given its share from the Marshall Plan and Mutual Security Act arrangements, in addition to American support for know-how and education to restructure and reform its state and industry (cf. Üsdiken, 2004). Üsdiken (2004: 258) argues that the established tradition of emulating the West (i.e. Europe) as the major source of learning and assistance since the late 18th century was now orientated towards the USA. Although the global dominance of the USA could be questioned presently, owing to the major financial crises it has been experiencing since 2008, its significant 'dominance effects' on Turkey in political, economic, and military arenas continue. Turkey is a less-advanced receiver country, with a strong tradition of transferring knowledge and practices from abroad, and whose relational ties with the 'dominant' sender country depict multilateral dependence (Üsdiken, 2004). Üsdiken and Wasti (2002) define Turkey as a 'receptive' country of (in particular Personnel and HR) management ideas originating from the USA. Erçek (2006) adds that HRM labels and ideas in Turkey are applied quickly owing to an instituted habit of emulating and successful adoption of Western practices.

Among the major differences between the key features of the home- and host-institutional systems, the most significant ones for the purposes of this article prevail in the education and financial areas. In Turkey, despite recent 'impressive' improvements (OECD, 2007), educational attainment and access to education at every level remain still significantly behind most OECD and EU countries. In the PISA (Programme for International Student Assessments by OECD) rankings, Turkey scores among the last five countries in every indicator. ${ }^{1}$ Quality of education continues to be very low, primarily as a result of significant disparities among schools, a shortage of teachers, and low socio-economic status of students. Consequently, there is a large but uneducated and unskilled workforce, while an educated and qualified workforce is still scarce. While the highly stratified American educational system is claimed to neglect mass education and provide an outstanding but 'elite' university education, it nevertheless produces potential employees with enough basic skills and education to accommodate the less-skilled labour needs of mass manufacturing sectors (Ferner, 2000). Although there is certainly a need for company-level training of blue-collar workers in both countries, the level of knowledge and skills available is much lower in Turkey than in the USA, as only 50 percent of the total population make it to the secondary education level (OECD, 2007).

The financial systems are completely opposite: credit-based in Turkey, where weak stock markets are underdeveloped (Tanyeri, 2010); equity-based in the US, where the main management ideology has become boosting 'shareholder value' in the short term, as a result of the intensifying 'shareholder capitalism' and accelerated international competition (O'Sullivan, 2000). Firms in Turkey do not experience a comparable pressure for demonstrating short-term achievements, as the publicly traded shares do not constitute a critical amount (Balaban and Kunter, 1997). Moreover, the leading holdings have their own banks, which extend credit lines for their affiliates (Alper and Öniş, 2003), 
although this has recently changed with the increased share of foreign capital through acquisitions and mergers (Bakır and Öniş, 2010).

\section{Labour market orientations}

A comparison of the LMO in the two countries helps to understand the institutional distance. Supply and demand for labour meet in extremely flexible external labour markets (ELMs) in the strongly 'market-oriented' American business system (Dore, 1989). High labour turnover rates and career mobility between firms are seen as natural. It is argued that standardized mass production helped create ELMs, while the short-termism of financial markets further encouraged 'numerical flexibility', i.e. labour perceived as a cost to be minimized where downsizing is considered the first way to achieve it during difficult times (Clark and Almond, 2006). There are few institutional or cultural constraints on ELMs and except for government regulation on discrimination (Myors et al., 2008), 'employment at will' is legal and commonly accepted. There are no regulatory pressures on employers to demonstrate that dismissals are fair. Indeed, Kochan et al. (1994: xiii) argue that the US labour market has long been 'a place where anything goes'.

Alongside the largely prevailing ELMs among US firms, there has also been a long tradition of developing firms' own, particularly managerial, employees within strong internal labour markets (ILMs). ILMs are characterized as closed systems where: i) access to job ladders is open only at a few entry-levels and opportunities for climbing the ladder are saved for 'incumbents'; ii) training and development is offered by companies; and, iii) long-term employment and career opportunities are provided within the same firm. Osterman (1988) argues that the ILMs were originally developed as an organizational solution to a combination of external problems, i.e. unionization threats, labour scarcity, and government regulation. Between the 1950s and 1980s, ILM systems were widely applied in the more strongly unionized sectors of the American economy and, from the 1960s, in a growing number of 'high road' non-union firms (Katz and Darbishire, 2000; Kochan et al., 1994). A more philosophical variant of the high-road approach was found in 'welfare capitalism', applied by some major American companies, including Eastman Kodak, Polaroid, DuPont, and IBM (Jacoby, 1997).

Since the beginning of the 1990s, however, ILMs have been under pressure in the USA for four main reasons: i) the effects of the shift from manufacturing to service industries, hence changes in the number and mixture of people employed in these sectors and skills requirements; ii) increased competition within tougher domestic and international markets, which has raised serious cost considerations; iii) improvements in technology that have changed not only production systems but also management and control practices (Osterman, 1999); and iv) pressures from 'shareholder capitalism' (O’Sullivan, 2000). Survey results provide evidence for the 'deterioration' of the American labour market in norms, career patterns (e.g. declining job tenures, increased job turnover, increased dislocation), wage determination, shifts in the external context that governs the labour market, and changes in the structure of the economy itself (Osterman, 1999). These findings are interpreted as indicators for weakening ILMs, and have been held responsible for the 'death' of internal managerial careers (Capelli, 1999), resulting in the increased use of ELM systems ${ }^{2}$ (Capelli, 1995; Osterman, 1999). While Capelli (1999) 
and Osterman (1999) tend to explain the changes in the LMO of American firms through external pressures, Grimshaw et al. (2001) argue that any transformation of ILMs as an internal organizational logic would be more likely to be forced by a combination of both external and internal factors. Butler et al. (2006) consequently claim that variations in employment system policies can be expected in different organizations, depending on how they choose to handle inherent tensions. For instance, the core-periphery model emerged as an 'innovative' method in response to macroeconomic uncertainty and flexibility arguments (Jackson et al., 1989).

The institutional distance between LMO in Turkey and the USA is not very significant at the regulatory level, while there are some differences at the cognitive and normative levels. Similar to the USA, Turkish companies have not been legally restricted in their staffing practices. The labour code of $2003^{3}$ brings restricting rules for 'fair' dismissal, equal employment opportunities, downsizing, and complete shutdowns. However, neither the letter nor the enforcement of the law is strong (Ararat and Bayazit, 2009). Suppressive laws make it difficult for workers to gain any power through unionization. Therefore, it is argued that Turkey's employment system is comparable to that of the USA in terms of legal flexibility granted to employers, where 'dismissals at will' have been widely applied by small and medium size firms, and seasonal/temporary employment has been traditional in cyclical industries. In the USA there is a stronger regulatory framework for certain employment issues, i.e. equal employment opportunities and discrimination, where laws and their enforcement are much stricter than those in other countries, including Turkey ${ }^{4}$ (Myors et al., 2008). Another significant difference between the two countries concerns the existence of a strong normative environment in the US, through the media (e.g. 'best companies to work for') and grass-roots societal pressure (e.g. campaigns against sweatshops). ${ }^{5}$ Such a normative context does not yet exist in Turkey: even pervasive collective actions do not get much (if any) attention from the media or the society at large.

Nevertheless provision of job security and long-term employment opportunities are traditionally observed in the large corporate sector in Turkey (Nichols and Sugur, 2004). This is in line with expectations of employees, who rank job security as the most important issue in employment relations (Y1ldirım, 1999). Large firms are found to prefer promotion from within, generally based on seniority (Uyargil et al., 2001). State-owned enterprises and government institutions, which have been among Turkey's largest employers, traditionally offer life-long employment. In return, employers expect loyalty from their employees (Sargut, 2001) and job-hopping is not perceived positively. Careers are usually made in the same company or holding, where cross-promotions between affiliates are widely applied.

Some parallels can be drawn between prevailing employment patterns in large Turkish employers and ILMs by American welfare capitalists. They both adopt ILMs in response to certain institutional factors: legally permissive environments, labour scarcity and, though to a limited degree in Turkey, threats of unionization. While welfare capitalists are opposed to unions on a philosophical basis - unions are perceived as a threat to managerial prerogative - in Turkey the opposition is more on economic and social grounds: unions are regarded as creators of unrest and economic loss in the workplace (Koç, 2006). ILMs are aligned with the paternalistic leadership styles of Turkish owners (and 
top-level managers) and the expectations of employees for protective and concerned 'bosses' more like a father figure (Sargut and Özen, 2001). As a result of a credit-based financial system and network relations (e.g. holding companies' own banks), the pressure for increasing 'shareholder value' is not as strong as in the USA. The cost of labour is significantly lower in Turkey than in developed economies, particularly considering moderate to high productivity levels (OECD, 2007). It is therefore easier to implement ILMs within this context of a less-advanced country.

\section{Method}

To investigate the research questions, case study method was used. Although quantitative studies provide broad pictures of comparative HRM policies and practices, contextual embeddedness of in-depth case studies allows a deep understanding of events, institutions, and processes, and their interaction within the particular context (Snow and Anderson, 1991).

Multiple cases were developed to increase the possibility of replication of findings, thus improving the generalizability of the case study (Eisenhardt, 1989; Yin, 1994). Case companies were selected from among American companies operating in Turkey by using analytically significant criteria, i.e. 'criterion-based' sampling (LeCompte and Preissle, 1993: 63), to ensure analytical generalizations. Accordingly, cases from a number of sectors were chosen to consider micro-institutional pressures by parent companies to adopt corporate operations and manufacturing systems, and the latter's influences on LMO. To identify leading American companies in Turkey, in addition to size and age, the significance of the subsidiary for Turkey (in terms of employment, amount of exports, deregulation), and the share of total and American FDI in the particular sector were used. At the time of the fieldwork, the largest share of American investment in Turkey $(72 \%)$ was in manufacturing, which was concentrated in food and drink, textiles, chemicals, and automobile production. Although services had a small share, two service companies that received considerable FDI after 2001 were included. ${ }^{6}$ To investigate the influences of corporate governance structures and local JV parents, subsidiaries where leading Turkish holdings are JV partners were identified. Consequently, seven American MNEs from different sectors were studied (Table 1).

Case studies were developed using data collected mainly by semi-structured interviews at subsidiary and regional headquarters and 79 interviews were conducted with a variety of actors (Table 2). The majority of the interviewees were from the HR departments: at the subsidiary level, HR Directors/Managers, Heads of sub-areas (e.g. Training and Development, Compensation, Recruitment and Selection), team leaders, specialists, as well as previous HR directors (in the cases where the historical information was significant). In the JV cases, HR Coordinators of the Turkish Holdings were also interviewed. At the regional headquarters of the US parents, top-level HR managers (e.g. Vice Presidents - VP) responsible from a (sub-) region (e.g. Europe, Middle East, or south Europe), or an HR function provided information from the corporate perspective. At the subsidiaries, other top-level managers (e.g. General Managers, Assistant General Managers, and Directors of major functional areas) were also interviewed where possible and relevant. While most of the interviewees at the subsidiary and the regional 
Table I Case study companies

\begin{tabular}{|c|c|c|c|c|c|c|}
\hline Company & Line of activity & $\begin{array}{l}\text { Ownership } \\
\text { structure }\end{array}$ & $\begin{array}{l}\text { Mode of } \\
\text { entry }\end{array}$ & $\begin{array}{l}\text { Industrial } \\
\text { relations }\end{array}$ & $\begin{array}{l}\text { No. of } \\
\text { employees } \\
\text { (Turkey) }\end{array}$ & $\begin{array}{l}\text { No. of } \\
\text { employees } \\
\text { (Global) }\end{array}$ \\
\hline AutoCOI & $\begin{array}{l}\text { Commercial } \\
\text { vehicles and cars; } \\
\text { manufacturing } \\
\text { and sales }\end{array}$ & $\begin{array}{l}\text { JV (equal US* } \\
\text { and TR*) }\end{array}$ & Brownfield & Unionized & 8000 & 201,000 \\
\hline FMCGI & $\begin{array}{l}\text { FMCG } \\
\text { (packaged food); } \\
\text { manufacturing } \\
\text { and sales }\end{array}$ & WOS & Brownfield & De-unionized & 510 & 48,000 \\
\hline FMCG2 & $\begin{array}{l}\text { FMCG (tobacco } \\
\text { products); } \\
\text { manufacturing } \\
\text { and sales }\end{array}$ & $\begin{array}{l}\text { JV (majority } \\
\text { US*) }\end{array}$ & Greenfield & Non-unionized & 1600 & 75,600 \\
\hline PharmaCOI & $\begin{array}{l}\text { Pharmaceuticals } \\
\text { (hospital care); } \\
\text { manufacturing } \\
\text { and sales }\end{array}$ & $\begin{array}{l}\text { JV (equal US* } \\
\left.\text { and } T R^{*}\right)\end{array}$ & Brownfield & De-unionized & 554 & 48,500 \\
\hline TexCO & $\begin{array}{l}\text { Clothing/ } \\
\text { garment; } \\
\text { manufacturing } \\
\text { and sales }\end{array}$ & $\begin{array}{l}\text { JV (majority } \\
\text { US*) }\end{array}$ & Greenfield & Unionized & 660 & 10,000 \\
\hline FinCO & $\begin{array}{l}\text { Retail and } \\
\text { corporate } \\
\text { banking }\end{array}$ & WOS & Greenfield & Non-unionized & 2249 & 350,000 \\
\hline HotelCO & Hotel & WOS & Greenfield & Non-unionized & 260 & 80,000 \\
\hline
\end{tabular}

JV: Joint venture; WOS: Wholly-owned subsidiary; *US: American partner, *TR: Turkish partner

headquarters were local, a total of 11 expatriates at both levels were also included among the interviewees. The last group of interviewees comprised union and employers' association officials (Table 3). Through information from, and perspectives of, various parties it was possible to benefit from the 'multi-perspectival' nature of case study research (Snow and Anderson, 1991: 154) and to triangulate data collected (Maxwell, 1996).

The number of interviews conducted in each of the case companies ranged between seven and 19. The variance was owing to company features and the level of access gained in each company. In the manufacturing cases, there were more managers to be interviewed in the plants. In the unionized and de-unionized (and two non-unionized cases, i.e. FMCG2 and HotelCO, where there had been unionization attempts) the number of interviews increased with the inclusion of union officials. In the JV cases, Holding HR coordinators were interviewed. The level of access gained in each company also varied, e.g. in FMCG2, despite several attempts, access was denied at the corporate headquarters.

Interviews were planned at the US headquarters to capture the corporate perspectives on international HR policy and to triangulate data. However, access proved impossible 
Table 2 Distribution of interviews

\begin{tabular}{|c|c|c|c|c|c|}
\hline Interview with & $\begin{array}{l}\text { HR management } \\
\text { (subsidiaries) }\end{array}$ & $\begin{array}{l}\text { HR management } \\
\text { (regional } \\
\text { headquarters) }\end{array}$ & $\begin{array}{l}\text { Other functional } \\
\text { managers (subsidiaries } \\
\text { and regional headquarters) }\end{array}$ & Unions & Total \\
\hline AutoCOI & 6 & 4 & 6 & 3 & 19 \\
\hline FMCGI & 5 & I & 3 & I & 10 \\
\hline FMCG2 & 7 & & 2 & I & 10 \\
\hline PharmaCOI & 4 & I & 2 & 2 & 9 \\
\hline TexCO & 5 & 3 & 6 & 3 & 17 \\
\hline HotelCO & 2 & 3 & I & I & 7 \\
\hline FinCO & 3 & 2 & 2 & $\mathrm{n} / \mathrm{a}$ & 7 \\
\hline TOTAL & 32 & 14 & 22 & II & 79 \\
\hline
\end{tabular}

Table 3 Distribution of interviews across the respondents

\begin{tabular}{|c|c|}
\hline Interview at & Interview with \\
\hline AutoCOI: TURKEY & $\begin{array}{l}\text { HR/IR Director (2); HR Specialist; HR Training Team Leader; } \\
\text { Holding I HR Coordinator and Assistant Coordinator; } \\
\text { Chief Finance Officer (expatriate); Vice General Manager } \\
\text { (expatriate); Assistant General Manager (Sales and Marketing; } \\
\text { expatriate); Assistant General Manager (Sales and Marketing); } \\
\text { Union officials (2); Employers' Association President }\end{array}$ \\
\hline EUROPE & $\begin{array}{l}\text { USAutol Europe HR Managers (2); Organisational Personnel } \\
\text { Planning Managers (2) }\end{array}$ \\
\hline FMCGI: TURKEY & $\begin{array}{l}\text { HR Director (3); Plant HR Manager; Previous HR Director; } \\
\text { Production Manager; Previous General Manager (expatriate); } \\
\text { General Manager; previous union's president }\end{array}$ \\
\hline EUROPE & $\begin{array}{l}\text { USFood Organisation and Capability Development Director } \\
\text { (expatriate) }\end{array}$ \\
\hline FMCG2: TURKEY & $\begin{array}{l}\text { HR Directors (2; one expatriate); HR Manager (2); Plant HR } \\
\text { Manager; Holding2 HR Coordinator; Previous HR Director; } \\
\text { Plant Production Manager; Sales and Distribution Director; } \\
\text { union official }\end{array}$ \\
\hline PharmaCOI: TURKEY & $\begin{array}{l}\text { HR Director; HR Manager; Plant Manager (expatriate), } \\
\text { Holding3 HR Coordinator and previous Coordinator; previous } \\
\text { union's officials (2); Employers' Association General Secretary }\end{array}$ \\
\hline REGIONAL & USPharmal HR Manager \\
\hline TexCO: TURKEY & $\begin{array}{l}\text { HR Manager (2); previous HR Manager; General Manager (3); } \\
\text { Finance Director; Sales Director; Union officials (3) }\end{array}$ \\
\hline EUROPE and Regional & $\begin{array}{l}\text { USTex IR Director Supply Chain (2; one expatriate); Divisional } \\
\text { HR Director }\end{array}$ \\
\hline $\begin{array}{l}\text { HotelCO: TURKEY } \\
\text { EUROPE }\end{array}$ & $\begin{array}{l}\text { HR Director (2); General Manager (expatriate); union officials } \\
\text { USHotel HR Director; HR Manager; Sub-regional HR Director }\end{array}$ \\
\hline FinCO: TURKEY & $\begin{array}{l}\text { Country HR Officer; VP HR Staffing and Communications; HR } \\
\text { Manager Training and Development; Chief of Staff }\end{array}$ \\
\hline EUROPE & $\begin{array}{l}\text { USFin Regional VP HR (2; one expatriate); Senior Manager } \\
\text { (EMEA; expatriate) }\end{array}$ \\
\hline
\end{tabular}


as no direct reporting and communication lines were established between the Turkish subsidiary and the American headquarters. In most companies, regional headquarters were in Europe and interviews with top-level HR directors were conducted face-to-face by the author. In two cases, where the Turkish subsidiaries reported to non-European regional headquarters, telephone interviews were held owing to financial and time constraints.

The interviews took place during spring and summer (March-August) in 2002, 2003 and 2004, mainly owing to the location of the case companies and work arrangements of the author. Arranging and conducting interviews at subsidiary (all in Istanbul) and regional headquarters in various European cities required unrestricted free time, hence the three intervals. Snow and Anderson (1991) argue that the case study conducted over time provides a major advantage as:

It facilitates the possibility of capturing and analysing events and happenings, interactions and relationships, and groups and institutions as they emerge and evolve across time. (p. 161)

Interviews on average lasted two hours. Except when respondents declined their consent (four managers and 11 union officers), 64 out of 79 interviews were taped and transcribed verbatim. Extensive notes were taken during the interviews that were not taped. Transcriptions and notes were coded and analysed by the author using specialized software QSR6.

\section{Findings}

Labour market orientations of the wholly-owned subsidiaries (WOS) (i.e. FMCG1, FinCO, and HotelCO) are uniformly reported as an ILM approach (Table 4). The interviewees in the Turkish subsidiaries start by describing their internal job postings and promotion from within policies in reply to questions about recruitment and selection policies. Evidently complementary HR policies for an ILM approach also exist: job ladders open mostly at the entry levels only and higher level positions reserved for 'incumbents'; formal and standardized job grading and job definitions; performance-related and competitive compensation; early identification and promotion of high potentials; high investment into internal training and development programmes; succession planning. The existence of an ILM approach and related policies in these cases are confirmed by the interviewees at the European headquarters and as a US corporate policy transferred to Turkey.

The JV subsidiaries (i.e. AutoCO1, PharmaCO1, FMCG2, TexCO) also report an ILM orientation, with almost identical HR policies and complementary practices. The only distinction is about whose corporate policy is transferred to the subsidiary: in AutoCO1 and PharmaCO1, ILM policies of Holding1 and Holding3 respectively are reported to have been transferred, while in FMCG2 and TexCO, they are reported as USFMCG2 and USTex corporate policies. AutoCO1 and PharmaCO1 rely completely on their Turkish parents for HRM systems, policies, and applications. In AutoCO1, various interviewees, including expatriates and those at the USAuto1's European HQ, confirm that Holding1's HRM policies and practices, including LMO and related policies, 


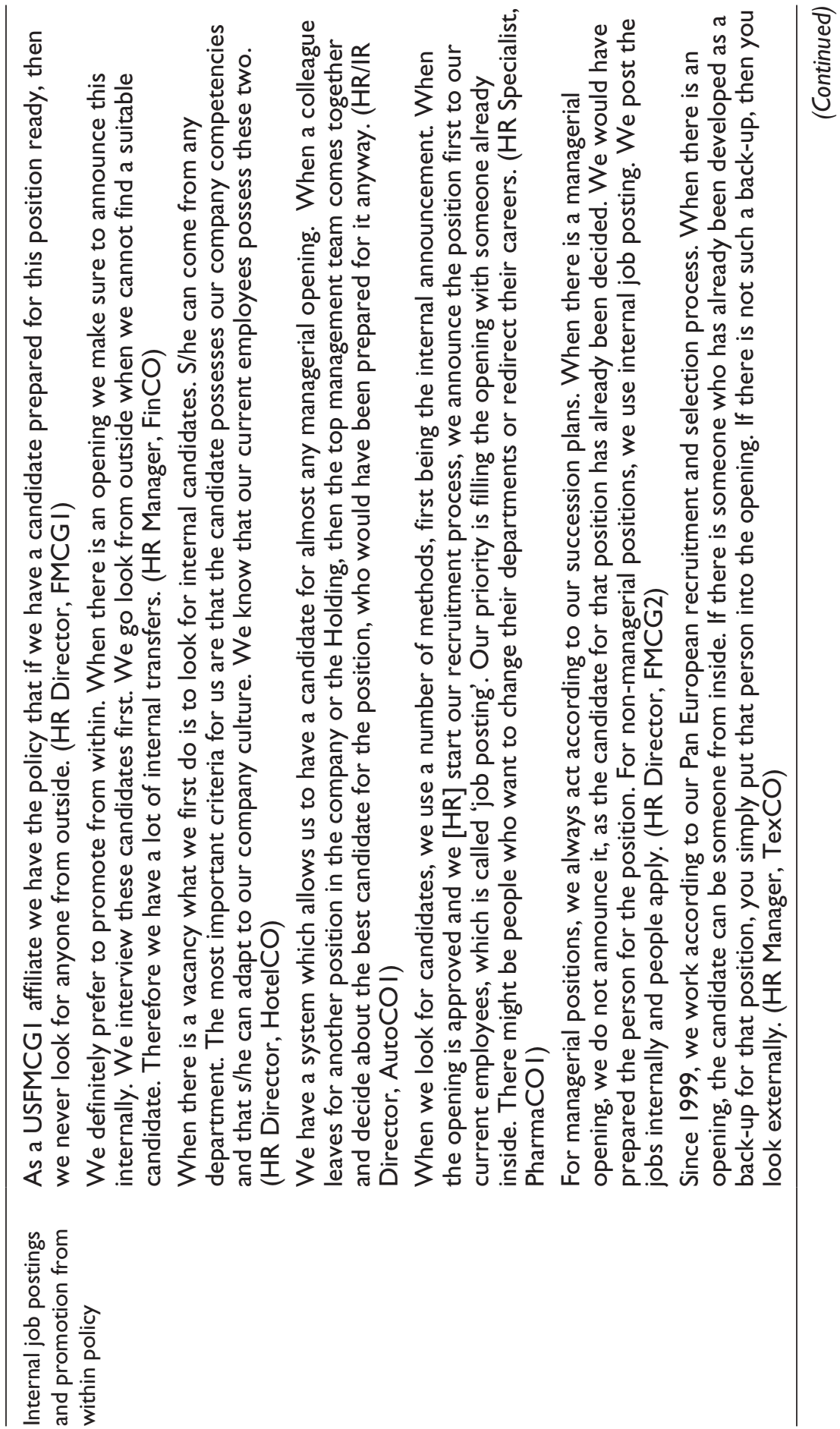




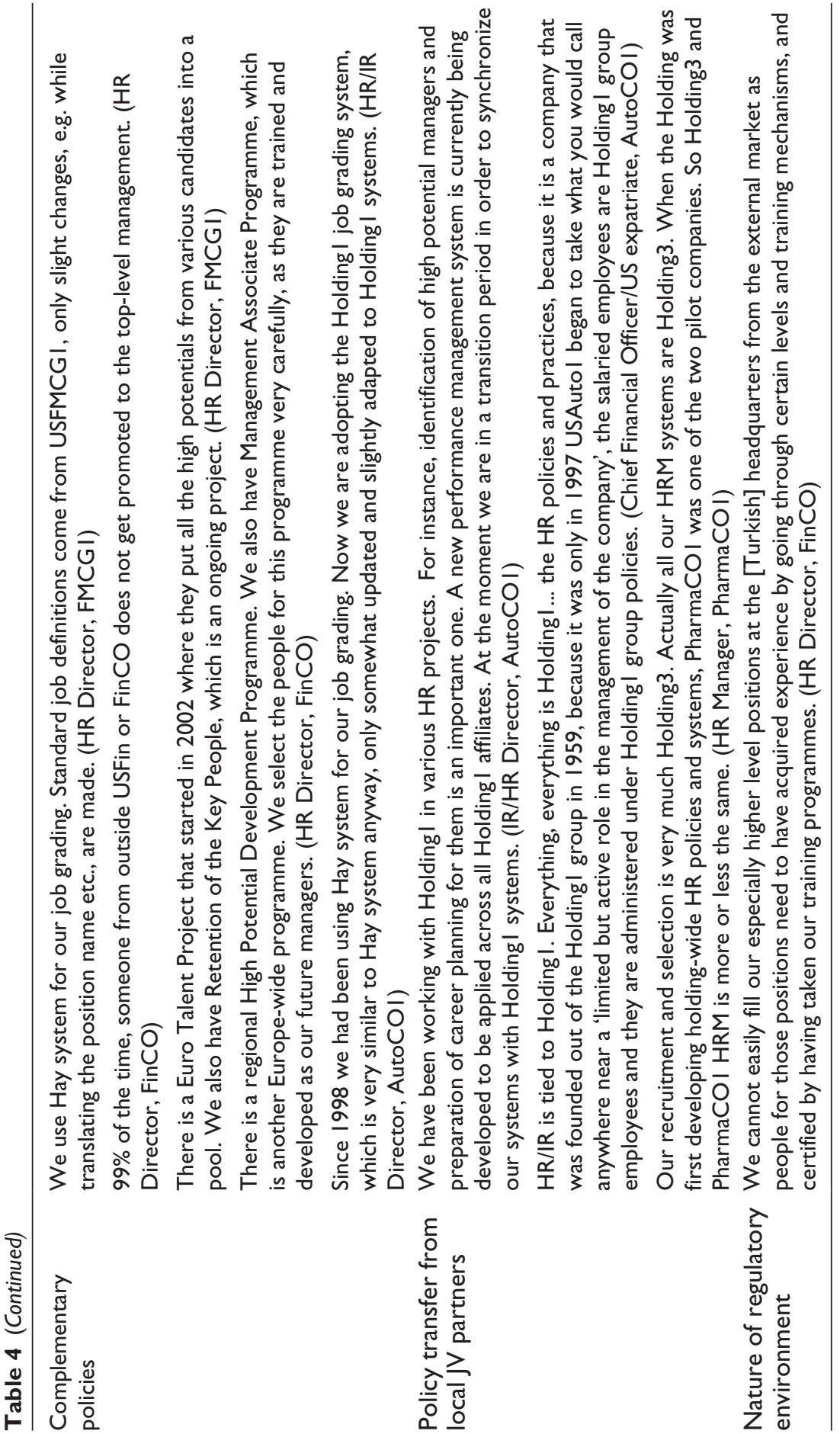




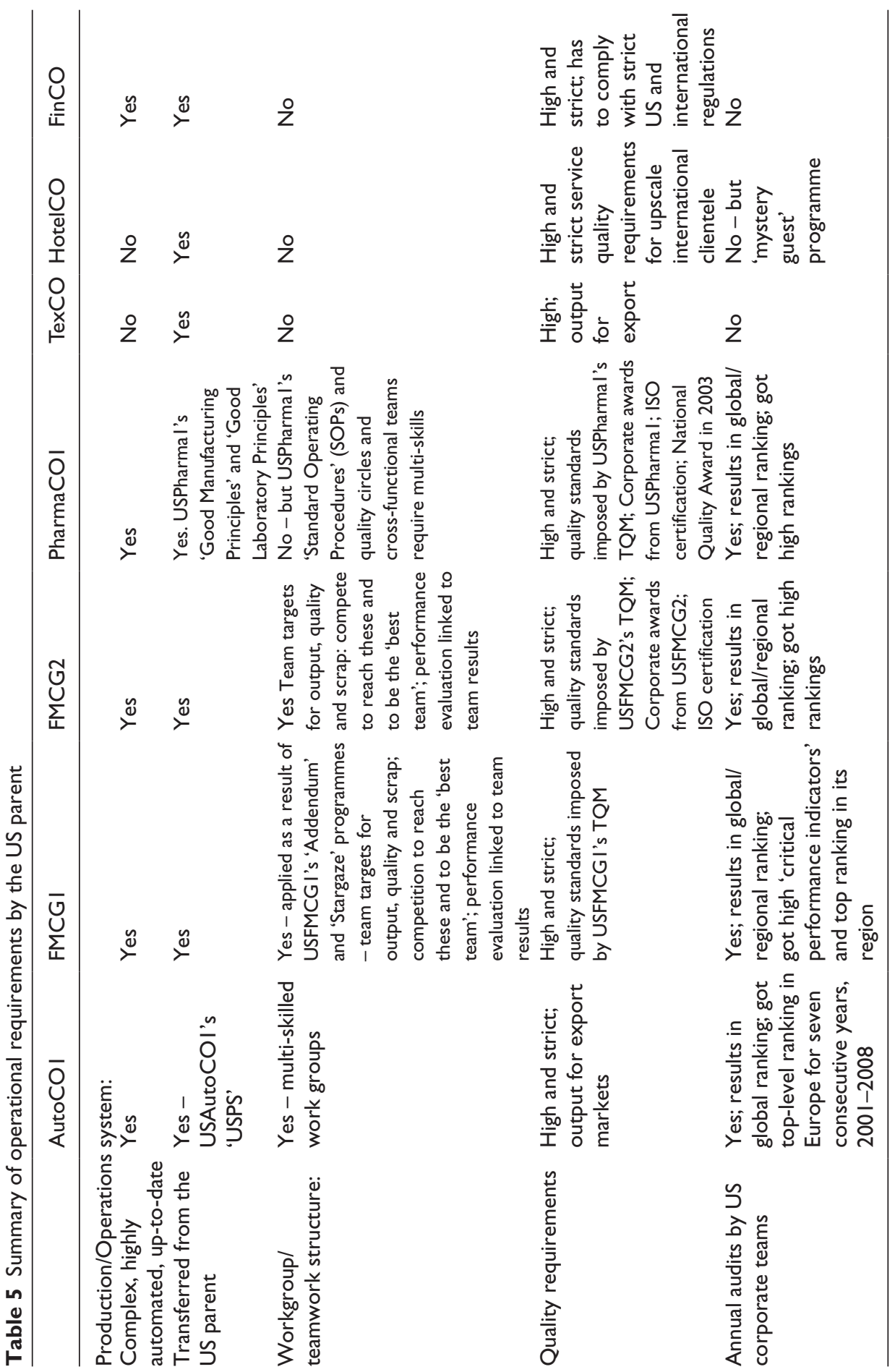


are transferred and applied. Similarly in PharmaCO1, HRM policies and practices developed, coordinated, and controlled by Holding3 are transferred. Contrary to these two JVs, in FMCG2 and TexCO, Turkish parents have minority shares and no managerial involvement, including HRM.

There are clear operational requirements that point towards use of an ILM in the case companies, regardless of the governance structure and sector (Table 5). All manufacturing cases (AutoCO1, FMCG1, FMCG2, PharmaCO1) except TexCO depend on their American parents for the highly complex and state-of-the-art production/operations systems transferred from the USA. To operate these systems and use teamwork structures successfully, while also complying with strict and high quality requirements and performing well in annual audits, case companies need to secure a multi-skilled and qualified workforce at both operational and managerial levels.

Cases from the services have similar conditions. Large multinational banks operate their complex and knowledge-based business using high technology. In FinCO these systems are transferred from its US parent, USFin, and FinCO is highly dependent on USFin for its operations. USFin compels its subsidiary to provide highest quality service and comply with the strict international and American regulations in the financial sector, intensified particularly after the infamous fraud cases of, for example, Enron and WorldCom. Thus the pressure for an ILM in FinCO comes partly from the nature of the international and local regulatory environments. The company must ensure that the behaviour of subsidiary personnel should avoid compromising the firm as a whole. Therefore firm-specific skills, developed and certified in-house, are significant reasons for the ILM approach at FinCO for its managerial and specialist positions.

As a traditionally labour-intensive service industry, where operations are simple, most tasks are clearly and tightly defined, and employees come from the unskilled end of the labour market, HotelCO can be regarded a most unlikely company in which to find an ILM. However, USHotel, a successful member of the few international luxury hotel chains, imposes pressure on HotelCO to deliver standardized top quality service to an exclusive international clientele. To comply with its parent's pressures for operational perfectionism, HotelCO needs a more-skilled, easily trainable workforce than in the hotel industry in general.

While providing evidence for ILM orientation in their companies, respondents did not hesitate to reveal such instances as dismissals and redundancies. For example, at TexCO, the HR Manager said that they carried out a strategic HR planning in Turkey as a part of the pan-European re-structuring process, and they 'moved out' those people who were in the same position for 10-15 years, resulting in 23 percent of the positions being replaced with 'new blood'. This did not mean a change in their ILM approach, however: they now have more elaborate and strictly controlled performance management systems in order to evaluate their employees and take early action when necessary. Similarly, when AutoCO1 was moving its production to its new facility, they could not take all their employees, as it required relocation. However, they kept all those who agreed to relocate, even though that meant 'carrying a few hundred workers more than we should' (CFO, AutoCO1). Both the CFO and HR/IR Director admitted that they had to do it in order not to lose the accumulated knowledge and experience in these workers throughout the years they had been employed at AutoCO1. In FMCG2, TexCO, HotelCO, and FinCO, interviewees 
admitted that they can sometimes 'lose people' as the organizations did not grow enough to accommodate a sufficient number of promotions. Therefore, they use other methods (training and development opportunities, job rotations, short/long overseas assignments, etc.) as 'the main objective is to keep our employees inside' (HR manager, FMCG2).

All but TexCO and HotelCO are highly dependent on their US parents for high technology and complex operating systems. For TexCO and HotelCO, the dependence on the US parent is more in terms of globally recognized brand name and expertise than operational systems. Moreover, all case companies evidently have high trust in the globally established brand names and expertise of their American parents. Particularly the WOS, and JVs where HRM belongs to the US parent (i.e. FMCG2 and TexCO), Turkish managers identify their companies highly with their American parents.

\section{Discussion and conclusion}

This article sets out to address the gaps identified in the literature, namely to understand how macro- and micro-institutional pressures influence policy transfer when it is intended from an advanced economy to a less-advanced one. The choice of home- and host-country is made to consider 'dominance effects' on the process. Local JV partners are incorporated into the framework as actors who have potential micro-institutional influences and might also act as 'transmission belts' for macro-influences. Within this research context, the findings deviate from the widespread results in the extant literature. The corporate ILM policies are transferred without problems, showing a uniform pattern of 'compliance', i.e. full conscious obedience (Oliver, 1991). In other words, LMO of corporate parents are implemented and 'internalized' (Kostova, 1999), despite large institutional distance between the home- and host-countries, which theoretically reduces the potential for transfer as a result of highly conflicting macro- and micro-institutional pressures (Kostova and Roth, 2002). Given that the literature generally asserts a variety of non-'acquiescence' responses by subsidiaries to corporate policy transfers even between countries of smaller institutional distance (e.g. Ferner et al., 2005a; Tempel et al., 2006), the unproblematic transfer to, and adoption of, policy in the host-country stands out. This finding can be explained by the combined nature of the institutional 'pressures' that work in different ways than those in the advanced economies, the role of local JV partners, and the specific policy transferred.

Despite the large institutional distance between the home- and host-country and different origins of the policy studied in them, there are no regulatory, cognitive, or normative obstacles in the host-country for the adoption of the policy. In fact, there is active 'institutional encouragement' as macro-institutional 'pressures' are reinforced by microinstitutional ones. At the macro-level, first, as a result of the education and skills development system, qualified and educated employees still belong to a small 'elite' group. If companies ought to secure such a workforce, who needs further in-house training and development, then an ILM approach is a viable option. The host environment further supports the application of the policy by considerably cheaper labour costs.

A second macro-institutional 'encouragement' is found at the normative level as ILMs and related practices are broadly diffused in the organizational field of the large corporate sector, particularly the Holdings, among which are the Turkish partners in two of the 
JV cases. Therefore, the role of local JV partners, conceptualized in the theoretical framework as an alternative source of isomorphism pressures, turns out to be one of 'encouraging pressures' as ILMs are transferred to the JV cases from their Turkish corporate parents. The role of the local JV partners gets even more complicated considering they have been among the early and 'vanguard' adopters of US-style HRM, mostly learning from their JV partners, and emulating home-country (particularly the US) practices (Erçek, 2006). This study provides a recognition of JV partners as a 'conduit for diffuse' home-country influences, particularly when the home-country has dominance effects on the host-country where its ideas and systems are regarded as a major source of learning and assistance. As such, the local JV partners transfer 'internalized' US-style HRM within the TBS to their JV (and other) affiliates, acting as 'transmission belts' that pass on macro-institutional 'pressures', one which seems from the outset more like microlevel pressures for the application of the specific policy.

The article provides evidence for 'active encouragement' also at the micro-institutional level. While high dependence on the MNEs for complex operating systems might act as an isomorphic pressure for adopting the policy, a more plausible explanation is the fit between the technological, operational, and efficiency needs of the companies and ILMs. As ILMs are expected to be pursued in technologically-advanced companies that depend on firm-specific skills (Dobbin et al., 1993), the case companies need to establish longterm employment relations and retain the workers trained for complex skills to avoid the high cost of finding and training new workers. Subsidiaries' positive response to microinstitutional pressures is unsurprising as they see economic 'fitness', i.e. anticipated economic gain, in adopting the policy. As such, transfer of the policy to, and adoption by, the subsidiaries is not unexpected, considering the macro- and micro-level 'encouraging pressures'.

This study demonstrates that a policy can be transferred smoothly when the macroand micro-institutional pressures for isomorphism are in the same direction and do not conflict with each other. Such an ideal combination of consistent pressures, providing 'active encouragement' rather than conflicting pressures, might be less commonly found. However, the article demonstrates that it is possible under the conditions explored, principally when the host-country is a less-advanced economy with a tradition of actively importing knowledge and systems from the advanced 'dominant' home-country. Therefore the findings provide evidence to broaden the range of countries in which to investigate policy transfer especially to less-advanced economies so as to validate existing models.

The significant role of the nature of the transferred policy in the ideal combination for smooth transfer should also be noted. Some policies might provoke resistance and hybridization if they directly confront main interests of key interest groups in the subsidiaries (Ferner et al., 2005a). This article shows that the argument also holds the other way around: when the policy serves the interests of all involved, then it can be transferred without 'resistive hybridization'. ILM orientation is such a policy that will not be objected to by employees, unions, or the government, so its application does not cause a 'dilemma of contradictory demands'. The unproblematic transfer is therefore supported by the nature of the policy in question. Accordingly, the role of the specific policy in the process as a significant factor needs to be taken into account when investigating transfer issues. 
The uncommon finding about straightforward policy transfer and adoption raises the question of 'decoupling', i.e. adopting a policy for legitimacy as a strategic response but not implementing it in practice (Meyer and Rowan, 1977). Decoupling can happen for a number of reasons: perceived conflict with technical efficiency, coercive pressures for implementation by legal bodies, pressures to mimic other firms in the sector to gain external legitimacy, or multiple and contradictory pressures on the organization (Boxenbaum and Jonsson, 2008). As discussed above, none of these potential reasons exist in the context of this study. Although evidence from below (i.e. employees) was not collected, sufficient verification from various actors involved (including unions) indicates that ILMs are indeed transferred to and applied in the case companies.

Additionally, this is a challenging policy to decouple just for the purposes of impression management. It is not too difficult to find evidence for the (non-) application of an ILM orientation; for example, the number of dismissals, redundancies, new hires, average length of service in the company. Moreover, the interviewees did not hesitate to provide even negative information on these. While this study, based on in-depth data, argues that the cases do not employ decoupling strategies for the transfer of ILMs, information collected from employees to get the full picture on the application of any policy will validate the actual implementation.

The findings from this study have implications for both the academic and the practitioner audience. As commonly argued in the extant literature, it is necessary to look beyond NBS framework to better understand policy transfer in MNEs. Micro-institutional pressures and the role of neglected actors (e.g. local JV partners) ought to be incorporated into the research frameworks. Echoing previous calls in the literature, more research in less-advanced economies is certainly needed to understand the role of not only different NBS but also the direction of transfer from advanced countries to less-advanced ones. Additionally, comparative cases from different home-countries operating in the same (particularly less-advanced) host environment might help differentiate more clearly between institutional and contextual influences. Finally, more heterogeneous sets of cases (e.g. from among MNEs operating in sectors where education and skills requirements are lower) need to be investigated as these might provide meaningfully different results. For the practitioner community, it is important to understand under which conditions policies can be transferred smoothly and what HR management can do towards this end. Subsidiary and corporate managers can collaborate to reduce 'conflicting pressures' and create 'active encouragement' for all actors involved to serve mutual benefits. In this way, less problematic policy transfer can be possible.

\section{Acknowledgements}

The author would like to express her gratitude to the Special Issue Editors, three anonymous reviewers, and Anthony Ferner, Michael Fichter, Ayşe Saka-Helmhout, and Behlül Üsdiken for their invaluable comments on earlier versions of this article.

\section{Funding}

This research received no specific grant from any funding agency in the public, commercial, or not-for-profit sectors. 


\section{Notes}

1. OECD Official website: http://pisacountry.acer.edu.au/

2. Although it is beyond the focus of this article, it must be noted that there has recently been some research suggesting major labour shortages in the USA aggravated by demographic changes, which had been a principal reason for an intensified interest in talent management. It might be possible that the need for talent management in companies can lead to a renewed interest in ILMs.

3. Law number 4857 , valid since $22 / 05 / 2003$, accessible at the official website of Ministry of Work and Social Security: http://www.csgb.gov.tr

4. I am grateful to an anonymous reviewer for this insight.

5. I am grateful to an anonymous reviewer for this point.

6. No published data for sectoral distribution according to host countries was available. These statistics were obtained from the Foreign Capital Directorate in an interview.

\section{References}

Almond P and Ferner A (eds) (2006) American Multinationals in Europe: Managing Employment Relations Across National Borders. Oxford: Oxford University Press.

Almond P, Muller-Camen M, Collings D and Quintanilla J (2006) Pay and performance. In: Almond P and Ferner A (eds) American Multinationals in Europe: Managing Employment Relations Across National Borders. Oxford: Oxford University Press, 119-145.

Alper CE and Öniş Z (2003) Financial globalization, the democratic deficit, and recurrent crises in emerging markets: The Turkish experience in the aftermath of caporal account liberalization. Emerging Markets Finance and Trade 39(3): 5-26.

Ararat M and Bayazit M (2009) Does the adoption of codes of conduct marginalise labour unions? The case of Turkey's garment sector. In: Mallin C (ed.) Corporate Social Responsibility: A Case Study Approach. Cheltenham: Edward Elgar, 216-257.

Arias ME and Guillén M (1998) The transfer of organizational techniques across borders: Neoinstitutional and comparative perspectives. In: Alvarez JL (ed.) The Diffusion and Consumption of Business Knowledge. London: Macmillan, 110-137.

Bakır C and Öniş Z (2010) The emergence and limits of the regulatory state: The political economy of Turkish banking reforms in the age of post-Washington consensus. Development and Change 41(1): 77-106.

Balaban E and Kunter K (1997) A note on the efficiency of financial markets in a developing country. Applied Economics Letters 4(2): 109-112.

Beaumont P and Townley B (1985) Non-union American plants in Britain: Their employment practices. Relations Industrielles 40(4): 810-825.

Berkman Ü and Özen Ş (2007) Turkish business system and managerial culture: State-dependency and paternalism in transition. In: Davel E, Dupuis J-P and Chanlat J-F (eds) Gestion en Contexte Intercultural: Approaches, Problematiques, Pratiques et Plongees. Quebec: Presse de l'Universite Laval et TELUQ/UQAM, 1-25.

Bjarnar O and Kipping M (1998) The Marshall Plan and the transfer of US management models to Europe: An introductory framework. In: Kipping M and Bjarnar O (eds) The Americanisation of European Business: The Marshall Plan and the Transfer of US Management Models. London: Routledge, 1-17.

Björkman I and Furu P (2000) Determinants of variable pay for top managers of foreign subsidiaries in Finland. International Journal of Human Resource Management 11(4): 698-713.

Bloom M, Milkovich GT and Mitra A (2003) International compensation: Learning from how managers respond to variations in local host contexts. International Journal of Human Resource Management 14(8): 1350-1367. 
Boxenbaum E and Jonsson S (2008) Isomorphism, diffusion and decoupling. In: Greenwood R, Suddaby R, Oliver C and Sahlin K (eds) Handbook of Organizational Institutionalism. London: SAGE, 78-98.

Buğra A (1994) State and Business in Modern Turkey. A Comparative Study. New York: SUNY Press.

Buğra A and Üsdiken B (1995) Societal variations in state-dependent organizational forms: The South Korean Chaebol and the Turkish Holding. Paper presented at EMOT Workshop, Helsinki, Finland.

Butler P, Collings D, Peters R and Quintanilla J (2006) The management of managerial careers. In: Almond P and Ferner A (eds) American Multinationals in Europe: Managing Employment Relations Across National Borders. Oxford: Oxford University Press, 172-194.

Capelli P (1995) Rethinking employment. British Journal of Industrial Relations 33(4): 563-602.

Capelli P (1999) Career jobs are dead. California Management Review 42(1): 146-167.

Clark I and Almond P (2006) Overview of the US business system. In: Almond P and Ferner A (eds) American Multinationals in Europe: Managing Employment Relations Across National Borders. Oxford: Oxford University Press, 37-56.

Colling T and Clark I (2002) Looking for 'Americanness': Home-country, sector and firm effects on employment systems in an engineering services company. European Journal of Industrial Relations 8(3): 301-324.

Çolpan A (2010) Business groups in Turkey. In: Çolpan A, Hikino T and Lincoln JR (eds) The Oxford Handbook of Business Groups. Oxford: Oxford University Press, 486-525.

Deeg R and Jackson G (2007) Towards a more dynamic theory of capitalist variety. SocioEconomic Review 5(1): 149-179.

DiMaggio P and Powell W (1983) The iron cage revisited: institutional isomorphism and collective rationality in organizational fields. American Sociological Review 48(2): 147-160.

Dobbin F, Sutton JR, Meyer JW and Scott RW (1993) Equal opportunity law and the construction of internal labor markets. American Journal of Sociology 99(2): 396-427.

Dore R (1989) Japan at Work: Markets, Management and Flexibility. Paris: OECD.

Edwards T and Ferner A (2002) The renewed 'American Challenge': A review of employment practice in US multinationals. Industrial Relations Journal 33(2): 94-111.

Edwards T, Colling T and Ferner A (2007) Conceptual approaches to the transfer of employment practices in multinational companies: An integrated approach. Human Resource Management Journal 17(3): 201-217.

Edwards T and Kuruvilla S (2005) International HRM: National business systems, organizational politics and the international division of labour in MNCs. International Journal of Human Resource Management 16(1): 1-21.

Eisenhardt K (1989) Building theories from case study research. Academy of Management Review 14(4): 532-550.

Elger T and Smith C (2006) Theorizing the role of the international subsidiary: Transplants, hybrids and branch-plants revisited. In: Ferner A, Quintanilla J and Sánchez-Runde C (eds) Multinationals, Institutions and the Construction of Transnational Practices: Convergence and Diversity in the Global Economy. London: Palgrave Macmillan, 53-85.

Erçek M (2006) HRMization in Turkey: Expanding the rhetoric-reality debate in space and time. International Journal of Human Resource Management 17(4): 648-672.

Ferner A (2000) The embeddedness of US multinational companies in the US business system: implications for HR/IR. DMU Business School Occasional Papers.

Ferner A and Quintanilla J (1998) Multinationals national business systems and HRM: The enduring influence of national identity or a process of 'Anglo-Saxonization'. International Journal of Human Resource Management 9(4): 710-731. 
Ferner A, Quintanilla J and Varul MZ (2001) Country-of-origin effects, host-country effects and the management of HR in multinationals: German companies in Britain and Spain. Journal of World Business 36(1): 107-128.

Ferner A, Almond P, Clark I, Colling T, Edwards T, Holden L and Muller M (2004) The dynamics of central control: Transmission and adaptation of 'American' traits in US multinationals abroad: Case study evidence from the UK. Organization Studies 25(3): 363-391.

Ferner A, Almond P and Colling T (2005a) Institutional theory and the cross-national transfer of employment policy: The case of 'workforce diversity' in US multinationals. Journal of International Business Studies 36(3): 304-321.

Ferner A, Almond P, Colling T and Edwards T (2005b) Policies on union representation in US multinationals in the UK: Between micro-politics and macro-institutions. British Journal of Industrial Relations 43(4): 703-728.

Ferner A and Tempel A (2006) Multinationals and national business systems: A 'power and institutions' perspective. In: Almond P and Ferner A (eds) American Multinationals in Europe: Managing Employment Relations Across National Borders. Oxford: Oxford University Press, $10-33$.

Gooderham PN, Nordhaug O and Ringdal K (1998) When in Rome, do they do as the Romans? HRM practices of US subsidiaries in Europe. Management International Review 38(2): 47-64.

Gökşen NS and Üsdiken B (2001) Uniformity and diversity in Turkish business groups: Effects of scale and time of founding. British Journal of Management 12(4): 325-340.

Grimshaw D, Ward KG, Rubery J and Beynon H (2001) Organisations and the transformation of the internal labour market. Work, Employment \& Society 15(1): 25-54.

Guest DE and Hoque K (1996) National ownership and HR practices in UK Greenfield sites. Human Resource Management Journal 6(4): 50-74.

Hartmann E, Feisel E and Schober H (2010) Talent management of western MNCs in China: Balancing global integration and local responsiveness. Journal of World Business 45(2): 169178.

Jackson SE, Schuler RS and Rivero C (1989) Organizational characteristics as predictors of personnel practices. Personnel Psychology 42(4): 727-786.

Jacoby S (1997) Modern Manors: Welfare Capitalism Since the New Deal. Princeton: Princeton University Press.

Katz H and Darbishire O (2000) Converging Divergences. Worldwide Changes in Employment Systems. Ithaca: Cornell University Press.

Kepenek Y and Yentürk N (2000) Türkiye Ekonomisi. Istanbul: Remzi.

Kipping M, Engwall L and Üsdiken B (2008) Preface: The transfer of management knowledge to peripheral countries. International Studies of Management and Organization 38(4): 3-16.

Kochan T, Katz H and McKersie R (1994) The Transformation of American Industrial Relations. Ithaca: ILR/Cornell University Press.

Koç Y (2006) Türkiye'de Sendikacılık: Sorunlar ve Çözüm Önerileri. In: Sazak F (ed.) Türkiye’de Sendikal Kriz ve Sendikal Arayışlar. Ankara: Epos, 157-207.

Kostova T (1999) Transnational transfer of strategic organizational practices: A contextual perspective. Academy of Management Review 24(2): 308-324.

Kostova T and Roth K (2002) Adoption of an organizational practice by subsidiaries of multinational corporations: Institutional and relational effects. Academy of Management Journal 45(1): 215-233.

Kostova T and Zaheer S (1999) Organizational legitimacy under conditions of complexity: The case of the multinational enterprise. Academy of Management Review 24(1): 64-81.

LeCompte MD and Preissle J (1993) Ethnography and Qualitative Design in Educational Research. San Diego: Academic Press. 
Lu Y and Bjorkman I (1997) HRM practices in China-Western joint ventures: MNC standardization versus localization. The International Journal of Human Resource Management 8(5): 614-627.

Martinez Z and Ricks DA (1989) Multinational parent companies' influence over human resource decisions of affiliates: US firms in Mexico. Journal of International Business Studies 20(3): 465-487.

Maxwell J (1996) Qualitative Research Design: An Interactive Approach. Thousand Oaks, CA: SAGE.

Meyer JW and Rowan B (1977) Institutional organizations: Formal structure as myth and ceremony. American Journal of Sociology 83(2): 340-363.

Myors B, Lievens F, Schoallert E et al. (2008) International perspectives on the legal environment for selection. Industrial and Organizational Psychology 1(2): 206-246.

Nichols T and Sugur N (2004) Global Management, Local Labour. Turkish Workers and Modern Industry. Basingstoke: Palgrave Macmillan.

OECD (2007) Reviews of National Policies for Education: Basic Education in Turkey. Paris: OECD.

Oliver C (1991) Strategic responses to institutional processes. Academy of Management Review 16(1): $145-179$.

O'Sullivan M (2000) Contests for Corporate Control. Corporate Governance and Economic Performance in the United States and Germany. Oxford: Oxford University Press.

Osterman P (1988) Employment Futures. Oxford: Oxford University Press.

Osterman P (1999) Securing Prosperity. Princeton: Princeton University Press.

Rosenzweig PM and Singh JV (1991) Organizational environments and the multinational enterprise. Academy of Management Review 16(2): 340-361.

Sargut S (2001) Kültürlerarası Farklılaşma ve Yönetim. Ankara: Imge.

Sargut S and Özen Ş (2001) Çalışanların Lider Davranışlarına İlişkin Beklentileri: Türkiye Üzerine Görgül Bir Araştırma. Manuscript.

Schmitt M and Sadowski D (2003) A rationalistic cost-minimization approach to the transfer of HR/ IR practices: Anglo-Saxon multinationals in the Federal Republic of Germany. International Journal of Human Resource Management 14(3): 409-430.

Shenkar O and Zeira Y (1987) Human resources management in international joint ventures: Directions for research. Academy of Management Review 12(3): 546-557.

Smith C and Meiksins P (1995) System, society and dominance effects in cross-national organisational analysis. Work, Employment and Society 9(2): 241-267.

Snow DA and Anderson L (1991) Researching the homeless: The characteristic features and virtues of the case study. In: Feagin JR, Orum AM and Sjoberg G (eds) A Case For the Case Study. Chapel Hill: University of North Carolina Press, 148-173.

Suchman MC (1995) Managing legitimacy: Strategic and institutional approaches. Academy of Management Journal 20(3): 571-610.

Tanyeri B (2010) Financial transparency and sources of hidden capital in Turkish banks. Journal of Financial Services Research 37(1): 25-43.

Taylor S, Beechler S and Napier N (1996) Toward an integrative model of strategic international human resource management. Academy of Management Review 21(4): 959-985.

Tempel A, Edwards T, Ferner A, Muller-Camen M and Wächter H (2006) Subsidiary responses to institutional duality: Collective representation practices of US multinationals in Britain and Germany. Human Relations 59(11): 1543-1570. 
Uyargil C, Özçelik O and Gönen D (2001) Cranfield Uluslararası Stratejik Insan Kaynakları Yönetimi Araştırması: 1999-2000 Türkiye Raporu. Istanbul: İşletme İktisadı Enstitüsü.

Üsdiken B (2004) Exporting managerial knowledge to the outpost: Penetration of 'human relations' to Turkish academia, 1950-1965. Management Learning 35(3): 255-271.

Üsdiken B and Wasti AS (2002) Türkiye'de akademik bir inceleme alanı olarak personel veya 'insan kaynakları' yönetimi. Amme İdaresi Dergisi 35(3): 1-37.

Y1ldırım E (1999) Modern management techniques in the developing world: The case of TQM and its impact on workers in Turkey. Work, Employment \& Society 13(4): 693-709.

Yin RK (1994) Case Study Research. London: SAGE.

Kadire Zeynep Sayım (BSc, MA, MBA, PhD) is Assistant Professor in Human Resource Management at Bilkent University, Turkey. Her main research interest is in employment relations in multinationals, focusing particularly on the interaction between cross-border policy transfers in multinationals, national employment systems, and micro-level influences in less-advanced countries. Her work has appeared in International Journal of Human Resource Management. [Email: kzeynep@bilkent.edu.tr] 